\title{
ŠPECIFICKÉ PODOBY SATIRY V DRAMATICKÝCH REALIZÁCIÁCH MILANA LASICU A JÚLIUSA SATINSKÉHO
}

\author{
LENKA HALUZOVÁ \\ Pedagogická fakulta Trnavskej univerzity v Trnave
}

\begin{abstract}
Anotácia: Štúdia pracuje s literárnoteoretickými poznatkami z oblasti komédie, pričom akcentuje satiru ako výrazový prvok komiky. Ťažisko štúdie tvorí komparácia literárnych predlôh s ich adaptáciami v dramatickej tvorbe Milana Lasicu a Júliusa Satinského. V štúdii sú identifikované satirické prvky prítomné v týchto adaptáciách ako výsledok žánrových posunov medzi pretextom a posttextom v rámci prislúchajúceho dobového kontextu vzniku diel.
\end{abstract}

Kl'účové slová: interpretácia, absurdná dráma, divadelná hra, komédia, humor

Jedným z atribútov hodnotovej orientácie literárneho textu vo všeobecnosti, ale aj nami skúmaných dramatických adaptácií, je dichotómia na osi tragickost' - komickost'. Charakter literárneho diela vo väčšine prípadov osciluje medzi týmito dvoma pólmi. Obidva vo vedomí prijímatel’a evokujú rozdielny zážitok. Postojová modalita v rovine drámy je realizovaná charakterovými črtami protagonistov, ako aj povahou interpersonálnych vztahov medzi nimi, ktoré vychádzajú z ich konania a obsahu ich replík. Nezanedbatelný vplyv má aj realizácia sujetu či výber prostredia. Všetky spomenuté atribúty formujú perspektívu textu, ktorá korešponduje so zámermi autora konštruujúceho fikčný svet svojho diela. ${ }^{1} \mathrm{~V}$ ontológii textu je recipientovi predložená aj určitá hodnotová orientácia, ktorú v procese percepcie diela dekóduje. Vyplýva z konkrétnej autorskej stratégie prostredníctvom postojovej modality.

Komickost', ktorou sa v štúdii zaoberáme, vzniká na základe rozporu vonkajšieho (formálna štruktúra) a vnútorného (sémantická štruktúra) usporiadania umeleckého textu. V rámci sémantickej štruktúry možno hovorit’ aj o nesúrodých dvojiciach (či už ide o predstavy, veci, predmety, myšlienky alebo slová), ktorých zdvojovanie vzdoruje primeranému uchopeniu. ${ }^{2}$ Uvedený rozpor ale nepostačuje na vyvolanie reakcie recipienta na komickost', ktorá býva konvenčne spájaná s pobavením a smiechom. Prijímatel' musí pri recepcii identifikovat’ a dešifrovat’ prítomné komické prvky v intencii autorského zámeru, resp. komickost’ musí byt’ signalizovaná. Vnímanie a správne uchopenie humoru či satiry v umeleckom texte teda súvisí najmä s rovinou komunikácie text - čitatel'. Zábavnost’ diela s komickými prvkami svojou zážitkovou hodnotou pripomína hru. ${ }^{3}$ Zál'uba v komike je prirodzený antropologický jav, ktorý funguje ako obranný mechanizmus, pričom pod povrchom jednoduchého žartovania sa často skrýva kritický postoj k negatívnym spoločenským javom. Jednou z foriem komickosti, využívanou na kritiku takýchto javov, je práve satira.

\footnotetext{
${ }^{1}$ ŽILKA, T. Text a posttext. Nitra : Univerzita Konštantína Filozofa, 2011, s. 62.

${ }^{2}$ BORECKÝ, V. Imaginace, hra a komika. Praha : Triton, 2005, s. 10.

${ }^{3}$ ŽILKA, T. Text a posttext, s. 63.
} 
Netriviálnym terminologickým problémom však býva jednoznačná definícia, hierarchia a usúvzṫažnenie pojmov satira, humor, irónia, sarkazmus, paródia či grotesknost', ktoré sú často použivané synonymicky. Problematickost’ vymedzenia daných pojmov spočíva $\mathrm{v}$ tom, že ich denotatívny význam je podobný, pretože všetky patria do množiny javov $\mathrm{v}$ rámci komiky. $\mathrm{V}$ monografii Text a posttext uvádza literárny teoretik Tibor Zilka kategorizáciu výrazových prostriedkov humoru a satiry, pričom humor a satiru považuje za základné formy realizácie komiky v umeleckom texte. ${ }^{4}$ Satiru od humoru odlišuje predovšetkým ofenzívnejší spôsob vyjadrovania komickosti, doplnený o kritiku kultúrno-spoločenských javov. Satira je v Žilkovom chápaní postavená na sarkazme a humor zase na irónii. Pre výrazové prostriedky irónie a sarkazmu je typická hyperbola (z nej vychádza paródia) a jazyková komika. V danom rozdelení je teda satira vo svojej podstate charakterová komika založená na sarkazme, pričom obsahuje prvky grotesky, hyperboly, paródie a v konečnom dôsledku aj jazykovej komiky.

Jednou z klúčových teoretických prác na túto tému je monografia François Rabelais a l'udová kultúra stredoveku a renesancie od literárneho vedca Michaila Michajloviča Bachtina. Poukazuje v nej na očistujúci účinok smiechu a odhal'uje deformácie spoločenského života, no zároveň nepopiera vážnost', skôr ju zbavuje jednostrannosti a skostnatenosti. Centrálnym pojmom v jeho uvažovaní o smiechovej kultúre je groteska. ${ }^{5} \mathrm{~V}$ závislosti na tom, ako široko tento pojem chápeme, ju možno vnímat' bud' ako jeden z výrazových prostriedkov humoru a satiry, alebo ako samostatný dramatický žáner. Literárna vedkyňa Margita Laczková vo svojej štúdii upozorňuje na rozlišovanie pojmov groteskný, tragikomický a absurdný. Groteska na rozdiel od tragikomického spája oba faktory (tragično a komično) do jedného harmonického celku a absurdnost' považuje za užší pojem než groteskno: „Mohli by sme povedat', že každá absurdnost’ je groteskná, reciprocita však neplatí." ${ }^{\prime \prime}$

Bachtin v spomínanom diele vyčleňuje tri typy grotesky: renesančnú, romantickú a modernú. Tibor Žilka k nim pridáva aj grotesku postmodernú. ${ }^{7}$ Priznáva jej atribút kritiky politického systému, najmä v kultúrno-spoločenskom priestore krajín strednej Európy v období komunistickej totality. ${ }^{8} \mathrm{~V}$ našej štúdii si na príklade konkrétnych textov všimneme premeny autorskej poetiky Milana Lasicu a Júliusa Satinského v nadväznosti na príslušný dobový kontext. Dvojica uvedených autorov vstúpila do slovenskej literatúry v šesṫdesiatych rokoch 20. storočia, ked’ sa kultúrno-spoločenská situácia oproti začiatku pät’desiatych rokov zmenila.

Jednou z dominantných tém povojnovej literatúry bola reakcia na vojnovú skúsenost', ktorá bola v domácej dráme tematizovaná najmä problematikou Slovenského národného povstania. Hrôzy druhej svetovej vojny v dráme západnej Európy podnietili vznik viacerých umeleckých smerov, medzi nimi existencializmu (Jean-Paul Sartre, Albert Camus) i tzv. absurdnej drámy (Samuel Beckett, Eugène Ionesco, Jean Genet). Ich vplyv sa po uvol’není spoločenských pomerov premietol do poetiky drá-

\footnotetext{
${ }^{4}$ Tamže.

${ }^{5}$ BACHTIN, M. M. Francois Rabelais a lidová kultura středověku a renesance. Praha : Argo, 2007, s. 18.

${ }^{6}$ LACZKOVÁ, M. Niektoré súvislosti medzi groteskou a postmodernizmom. In Romboid, 1994, roč. 29,

${ }^{7}$ ŽILKA, T. (Post)moderná literatúra a film. Nitra : Univerzita Konštantína Filozofa v Nitre, 2006, s. 66.

${ }^{8}$ Tamže, s. 76.
} č. 6 , s. 51 . 
my šest’desiatych rokov aj v Československu. Ohlas existencializmu v slovenskej dráme sa ukazuje najmä v textoch Leopolda Laholu (Bezvetrie v Zuele, Štyri strany sveta, Atentát) či Ivana Bukovčana (Kým kohút nezaspieva, Sneh nad Limbou).

Dovŕšenie osamostatnenia absurdných drám od ostatných literárnych smerov môžeme nájst’ v publikácii dramatika Martina Esslina Divadlo absurdity z roku 1961. Vydanie Esslinovej knihy bolo, ako konštatuje teatrológ Miloš Mistrík, priaznivé aj pre vznik a vývoj absurdného divadla na Slovensku: „Esslinov opis fenoménu absurdného divadla na začiatku šest’desiatych rokov prišiel z nášho hladiska vo vhodnom termíne. Komunistický východný blok prežil katarziu roku 1956, ked’ na XX. zjazde Komunistickej strany Sovietskeho zväzu vtedajší prvý tajomník Nikita Sergejevič Chruščov odhalil zločiny stalinizmu, a od konca pätdesiatych po koniec šesṫdesiatych rokov nastalo obdobie relatívneho uvolnenia (...). “9 Základným pocitom protagonistov absurdnej drámy bola dezilúzia, do určitej miery postavená na dištancovaní sa od dovtedajšej divadelnej tradície a na reflektovaní vnútorného sveta človeka po druhej svetovej vojne. Mistrík túto dezilúziu, v súlade s Esslinom, charakterizuje ako rozpad starých istôt a bezmocnost' človeka voči realite. ${ }^{10}$

Poetika absurdnej drámy najskôr začala do slovenského divadla prenikat' len v rovine zvýšenej miery grotesknosti a miešania komického s tragickým, ${ }^{11}$ čo identifikujeme v dielach Petra Karvaša z druhej polovice pätdesiatych rokov či v Bukovčanovej dráme Slučka pre dvoch. Inscenácie diel absurdnej drámy od európskych autorov na slovenskej scéne poukázali na tendenciu interpretovat' v nich skôr satirizujúce podobenstvá. ${ }^{12}$ Prvým autorom, ktorého hry môžeme do tohto literárneho smeru zarad'ovat', bol básnik a prekladatel' Rudolf Skukálek. Do polovice šest'desiatych rokov napísal hry Hodinky (1963), Metla (1964) a Piliny (1965), ktoré sa zaslúžili o prienik absurdnej drámy do podmienok slovenského divadelníctva, a to napriek tomu, že autor musel po auguste 1968 emigrovat’ a povedomie o ňom sa zo spoločnosti postupne vytratilo.

\section{Autorská poetika Milana Lasicu a Júliusa Satinského}

Povojnová literatúra je podla niektorých teoretických koncepcií chápaná ako koniec moderny a začiatok postmoderny, prípadne je považovaná za akúsi protopostmodernu. ${ }^{13}$ Pocity vykorenenosti, prázdnoty a nezmyselnosti či spochybnenie základných hodnôt človeka v absurdnej dráme boli transformáciou vojnových hrôz. $\mathrm{V}$ textoch domácej proveniencie sa $\mathrm{k}$ týmto pocitom pridružila aj reakcia na mašinériu politických procesov pätdesiatych rokov a totalitnú cenzúru v umení. Výsledkom daného spojenia bol o to silnejší satirický a groteskný charakter absurdného divadla v Československu. Milan Lasica, ktorý popri inom prekladal a aj režíroval texty významného predstavitel'a tohto umeleckého smeru v Pol’sku Sławomira Mrożeka, bol

\footnotetext{
${ }^{9}$ MISTRÍK, M. Slovenská absurdná dráma. Bratislava : VEDA, 2002, s. 12.

${ }^{10}$ Tamže, s. 13.

${ }^{11}$ ŠTEFKO, V. Roky šest'desiate a d’alšie. In Dejiny slovenskej drámy 20. storočia. (Ed. V. Štefko). Bratislava : Divadelný ústav Bratislava, 2011, s. 455.

12 Tamže, s. 456.

${ }^{13}$ Napr. podla spisovatela Martina Kasardu absurdná dráma a nový román už nesú prvky postmoderny. KASARDA, M. Povedz mi, čo čítaš, čiže dlhšia prechádzka súčasnou literatúrou čast̉ 3. In Dotyky, 1997, roč. 9, č. 3, s. 52 .
} 
už na začiatku svojej kariéry dobre oboznámený s poetikou absurdnej drámy. Aj ked' prenikanie jej vplyvu bolo pomalšie pre ideologicky motivovaný odpor literárnej kritiky v pätdesiatych rokoch, prekonaniu bariéry voči absurdnej dráme pomohol v socialistickom Československu práve Mrożek. Inscenácie jeho textov na slovenských javiskách výrazne prispeli $\mathrm{k}$ formovaniu absurdnej drámy u nás.

Dvojica Lasica a Satinský sa v šest’desiatych rokoch rýchlo etablovala v Divadle na korze. Inšpiráciu čerpali nielen z Becketta či Mrożeka, ale aj z estetiky kabaretu, tradície malých divadiel, tvorby Jiř́ího Voskovca s Janom Werichom, spoločenskej satiry Ivana Stodolu či renesančného divadla s prvkami improvizácie v duchu commedie dell'arte. Svojím neskrývaním sa za dramatické postavy im ako inšpiračný zdroj poslúžili aj českí herci Ivan Vyskočil a Jiří Suchý. Druhý menovaný na konci pät’desiatych rokov založil spolu s Jiřím Šlitrom divadlo Semafor, ktorého scénická produkcia pokračovala v tradícii Osvobozeného divadla. Neskorší smer tvorby Lasicu a Satinského ovplyvnili českí absurdisti, najmä Václav Havel (Vyrozumenie, 1966), neskôr preložili i jeho divadelné hry. Podla Martina Porubjaka sa v tvorbe Lasicu a Satinského môžeme, najmä čo sa týka typickej atmosféry a naladenia, opierat’ aj o vplyvy filmovej tvorby režiséra a herca Charlieho Chaplina (najmä v tom, že za úsmevmi komikov je často cítit’ skepsu a rozčarovanie zo sveta), nemej grotesky a dadaizmu. ${ }^{14}$

Pluralita inšpiračných prameňov, ktoré sú často v drámach Lasicu a Satinského parodizované, evokuje poetiku postmoderny. Parodovanie má v podaní autorskej dvojice povahu subverzie voči pretextu. Literárny vedec Peter Zajac v nadväznosti na dramaturgičku Barbaru Johnsonovú a literárneho teoretika Jeana-Francoisa Lyotarda zarad'uje subverziu medzi centrálne pojmy postmoderny. ${ }^{15} \mathrm{~V}$ našom chápaní sa v diele Lasicu a Satinského realizuje ako subverzia pôvodného textu alebo ako vytváranie ambivalentnosti a paradoxnosti $\mathrm{k}$ nemu. Autori teda netvoria negáciu k originálu, ale ho posúvajú do roviny, v ktorej má pozmenený význam, najčastejšie prostredníctvom hyperbolizácie, parodovania a špecifickej jazykovej komiky. Zretel'ne to môžeme interpretovat’ v skeči Jánošík, ktorý bol v televízii odvysielaný v rámci programu Ktosi je za dverami (1981). Parodizáciou jánošíkovskej topiky vytvárajú v konečnom dôsledku subverziu $\mathrm{k}$ mnohým verziám jedného z dominantných národných mýtov. Konečný posttext tak nie je negáciou originálneho príbehu, ale skôr zosmiešnením inventáru umeleckých výrazových prostriedkov asociovaných s jánošíkovskou tematikou v literárnej tradícii, pôvodná logika literárneho kánonu je úmyselne destabilizovaná.

Na úrovni makrokompozície sú dramatické texty Lasicu a Satinského adaptáciami rôznych diel domácej i svetovej literatúry. Treba zdôraznit, že v tomto prípade ide o adaptáciu, nie aktualizáciu pôvodných textov. Obidva pojmy označujú úpravu určitého diela, no rozdiel je v realizácii. Aktualizácia je operáciou, pri ktorej sa mení vročenie a dejový rámec. ${ }^{16}$ Najčastejšie ide o prispôsobenie pôvodného diela súčasnému publiku. Na druhej strane, „adaptácia na rozdiel od divadelného prekladu alebo aktualizácie má povolenú mimoriadnu slobodu a smelo modifikuje zmysel pôvodného diela (...), adaptovat’ znamená úplne prepísat’ text, ktorý sa považuje

\footnotetext{
${ }^{14}$ PORUBJAK, M. Lasica \& Satinský \& my. In LES. Levice : Koloman Kertész Bagala, 1996, s. 329.

${ }^{15}$ ZAJAC, P. Štylistika, rétorika, poetika. In Od moderny k postmoderne. (Ed. T. Žilka). Nitra : Univerzita Konštantína Filozofa v Nitre, 1997, s. 36.

${ }^{16}$ PAVIS, P. Divadelný slovník. Bratislava : Divadelný ústav, 2004, s. 35.
} 
iba za materiál. “17 Texty dvojice komikov sa teda v rovine makroštruktúry javia skôr ako adaptácie než ako metatexty. Potvrdzuje to aj Tibor Žilka, ktorý intertextualitu v týchto dielach vníma ako „marginálnu“"18, z dôvodu, že nadväzovanie na pretext je len na úrovni mikrokompozície a slúži na evokáciu pôvodného diela. Takýto typ postmoderného literárneho diela, kde autor konštruuje fikčný svet svojho textu na základe rozsiahleho prepracovania fikčného sveta pôvodiny, označuje literárny teoretik Lubomír Doležel ako mutáciu. ${ }^{19}$ Vyčleňuje tri typy postmoderných prepisov transpozíciu, rozšírenie a mutáciu, ktorú považuje za najradikálnejší druh prepisu, pretože podlamuje legitimitu pôvodného kanonického fikčného sveta. ${ }^{20}$

V podaní Lasicu a Satinského je táto „podvratná“ činnost̉ voči originálu realizovaná použitím satirickej optiky, ktorá však slúži viac ako kritika a demaskovanie negatívnych l'udských vlastností, než by sa usilovala zosmiešnit pretext ako taký. Priliehavejším terminologickým označením tu môže byt’ ekfráza. Tento termín má viacero významov, pričom najmä pol’ská literárna veda ho používa na charakterizovanie autorskej stratégie, ked’ umelec vo svojom diele tlmočí vlastné vnímanie iného umeleckého diela. ${ }^{21}$ Ide teda o umelcovu interpretáciu iného textu. Diferenciácia medzi metatextovou nadväznostou a ekfrázou v tomto smere však v rámci súčasnej literárnej vedy nad’alej ostáva nezretel’ná. Situácia v oblasti slovenskej činohry sa síce po roku 1956 čiastočne uvol’nila, no približne do roku 1962 bolo cenzurované všetko, čo bolo v rozpore s marxistickým svetonázorom a čo i len vzdialene odkazovalo na existencializmus, vrátane absurdnej drámy.22 Uchopit poetiku prohibitných textov sa v druhej polovici šest’desiatych rokov darilo divadlám malých javiskových foriem a divadlám štúdiového či autorského typu. Začiatok ich činnosti sa viaže ešte ku koncu pätdesiatych rokov, ked' v Čechách vznikli divadlá Na zábradlí, Semafor, Rokoko, Činoherní klub či Divadelní studio v Ústí nad Labem. Divadelný historik Vladimír Štefko na margo dobovej situácie u nás uvádza: „Na Slovensku sa hnutie tzv. malých javiskových foriem začalo formovat's asi pätročným oneskorením, a i to na amatérskej, najmä vysokoškolskej báze. Pokusy o profesionálne súbory nedopadli slávne. (...) No už na začiatku sedemdesiatych rokov (...) priniesla druhá vlna slovenských malých foriem rad autorov, ktorí sa časom prestali uspokojovat's tvorbou pásiem, kabaretov a satirických feérií a objavili v sebe ambíciu písat’ aj pre profesionálne divadlo (...). ${ }^{\text {} 23}$

Za mílnik v inscenovaní absurdných hier môžeme považovat' uvedenie hry Soirée (1968) a Beckettovej hry Čakanie na Godota (1968, réžia Vladimír Strnisko a Milan Lasica) v Divadle na korze. Toto divadlo v rokoch 1968 - 1970 prijímalo a spracúvalo divadelné inšpirácie z tzv. západnej literatúry a usilovalo sa inscenovat’ texty zahraničnej absurdnej drámy. Z krátkych programových vyhlásení vyplýva, že dramaturgia si stanovovala ciele súvisiace s prínosom a vstrebávaním impulzov z európskej divadelnej tvorby.

${ }^{17}$ Tamže, s. 26 .

${ }_{18}$ ŽILKA, T. (Post)moderná literatúra a film, s. 15.

${ }^{19}$ DOLEŽEL, L. Heterocosmica (Fikce a možné světy). Praha : Karolinum, 2003, s. 203.

${ }^{20}$ Tamže.

${ }^{21}$ JEDLIČKOVÁ, A. - FEDROVÁ, S. Obraz v př́běhu - ekfráze ve vyprávění. Předběžné návrhy k rozlišení popisnosti a vizuality. In Slovenská literatúra, 2010, roč. 57, č. 1, s. 39.

22 JABORNÍK, J. Vývinové premeny slovenskej divadelnej réžie a generačná otázka. In Poetika a politika. (Ed. J. Pašteková). Bratislava : Ustav slovenskej literatúry SAV, 2004, s. 153.

${ }_{23}^{23}$ ŠTEFKO, V. Roky šest'desiate a d’alšie. In Dejiny slovenskej drámy 20. storočia, s. 457 - 458. 


\section{Márna lásky snaha}

Zmena politickej klímy po invázii vojsk Varšavskej zmluvy do Československa sa významným spôsobom dotkla aj tvorivých aktivít Milana Lasicu a Júliusa Satinského, ktorí boli počas prvej polovice sedemdesiatych rokov proskribovaní. Ich neoficiálny návrat do slovenskej literatúry predstavuje úprava hry ideologicky afirmovaného dramatika Jána Soloviča Plné vrecká peňazí na Novej scéne (1975). V roku 1978, v komédii Williama Shakespeara Márna lásky snaha, ktorú režíroval Miloš Pietor, Lasica so Satinským vystavali druhý obraz štvrtého dejstva takým spôsobom, aby úvod a záver obrazu ostali vel'mi podobné originálnemu dielu. Príčiny tejto autorskej stratégie možno nájst’ v snahe o zachovanie dramaturgickej plynulosti v rámci Pietorovej scénickej interpretácie. Komickost’ na úrovni textu ako celku spočíva v umeleckej hyperbolizácii Shakespearovho tvorivého postupu.

$\mathrm{V}$ tomto diele renesančného dramatika je siginifikantné použitie slovných hier a satiry, ktorá je nasmerovaná voči prejavom prehnanej učenosti protagonistov. Teatrologička Jana Bžochová-Wild upozorňuje aj na paralelu s Chválou bláznivosti Erazma Rotterdamského. ${ }^{24}$ Jedným z príkladov použitia slovnej hry je konštruovanie novotvarov a skomolenín zo slov anglického jazyka, ktoré autori zámerne spájajú s domácimi lexémami, napr.: „Ja osobne mám vel’mi rád lov. Ako my Angličania hovoríme - ajlovjú... Človek sa s chutou oddáva zabíjaniu, a pritom sa nespreneverí svojmu svedomiu. “25 Satirický moment tu vzniká na základe fonetickej podobnosti slov z dvoch rôznych jazykov, vd’aka ktorej sa zvrat "ajlovjú" v domácom jazyku diela dostáva do novej sémantickej roviny. Lasica a Satinský využívajú aj iné postupy utvárania slovných hier, napr. premenovávaním názvov určitých reálií. Robia to prostredníctvom rozličných, na prvý pohl'ad nelogických myšlienkových postupov, ktoré vznikli na báze asociácií, napr. podl'a zvuku, ktorý vydáva daný predmet, alebo podl'a činnosti, ktorú vykonáva. Spisovatel’ a literárny kritik Kornel Földvári hru so slovom u Lasicu a Satinského posúva až do oblasti reči ako ustáleného systému zvukov, pri ktorých na lexikálnom význame nezáleží, no funkčne vypĺñajú ticho. ${ }^{26}$ Vzniká tak nesúlad medzi zvukovou a obsahovou vrstvou, teda de facto odcudzenost' týchto dvoch zložiek.

Vrcholom divadelno-dramatického stvárnenia l’udského odcudzenia a jazykovej nezrozumitel'nosti u Lasicu a Satinského bolo podla Miloša Mistríka vytvorenie vlastného umelého, nezrozumitel'ného absurdistického jazyka, migzidštiny. ${ }^{27}$ Umelé skonštruovanie absurdného jazyka môžeme interpretovat ako paródiu jazyka a slovenského literárneho „folklóru“, zároveň ako vyjadrenie vonkajšej i vnútornej izolácie človeka neschopného výmeny myšlienok prostredníctvom slov, čo je charakteristický znak absurdnej drámy. Slová sa osamostatňujú od pojmov, strácajú zmysel a realizujú sa len vo forme akustických signálov.

Rozšíreným spôsobom realizácie slovnej hry Lasicu a Satinského je aj kalambúr, ktorý využíva zvukovú podobnost' slov. V ich interpretácii Márnej lásky snahy hovorí

\footnotetext{
${ }^{24}$ BŽOCHOVÁ-WILD, J. Shakespeare. Zooming. Bratislava : Európa, 2017, s. 86 - 87.

${ }^{25}$ LASICA, M. - SATINSKÝ, J. Márna lásky snaha. In LES 2. Levice : Koloman Kertész Bagala, 1998, s. 167.

${ }^{26}$ FÖLDVÁRI, K. Svet pre dvoch. Levice : Koloman Kertész Bagala, 2004, s. 17.

${ }^{27}$ MISTRÍK, M. Slovenská absurdná dráma, s. 119.
} 
Nathaniel: „Tak teda! Hla, tamto v dial'ke beží divá zver po lúke a čosi šípi. Natiahnem tetivu, a šíp už letí z luku na lúku a zabodne sa do tej divej svine, tým pádom je z tej divej svine zrazu ošípaná. “ 28 Často používaným javom je aj hra s homonymami, ktorých polysémantickost’ vytvára v texte viaceré možné interpretovatel’né významy, čo tiež možno ilustrovat’ na výroku Nathaniela: „A vytiahni si z brucha ten šíp! Ešte si budú mysliet', že si trafený!“"29

Ďalšia postava, Holofernes, v hre navonok predstavuje intelektuála, ktorého humor je kreovaný využívaním špecifických lexikálnych prostriedkov: „V tomto epitetón konstáns sa mi podarilo s razanciou mne vlastnou spojit dve úplne odlišné slová - a síce prapodivno, podstatné meno podla vzoru brvno, a úchvatný, prídavné meno prvého stupňa. “30 Lasica a Satinský ironizujúcim použitím termínov z rôznych vedných oblastí karikujú pomocou umeleckej hyperboly prototyp učenca, ktorý sa za každých okolností snaží vystavovat’ na obdiv svoju duchaplnost’ a vedomosti. To zároveň môžeme označit’ za alúziu na didaktizujúci charakter renesančných literárnych diel.

\section{Deň radosti}

Iný typ dramatickej realizácie v tvorbe Milana Lasicu a Júliusa Satinského reprezentuje hra v dvoch častiach Deň radosti, uvedená v Štúdiu S v roku 1986. Pre lepšie uchopenie kultúrno-spoločenského významu, a to nielen satiry, ale aj komiky ako takej, je dobré sa vrátit’ k spoločenskej situácii pät’desiatych rokov minulého storočia a pozriet' sa na satiru z dobovej perspektívy.

Jedným z dominantných atribútov satiry je reakcia na spoločenskú situáciu formou výsmechu. Spoločenská satira totiž často reflektuje skutočné nálady v spoločnosti, takže aj napriek alegorickosti a náznakovosti bývajú negatívne javy v takomto umeleckom diele zretel’ne identifikovatel'né a dekódovatelné. Politické elity boli vždy vel’mi vnímavé k vlastnému zosmiešňujúcemu obrazu v umení. Svedčia o tom aj konzekvencie ždanovovskej estetickej doktríny nielen v Sovietskom zväze, ale aj v socialistickom Československu. Socialistický realizmus a jeho ideologický tlak na umelcov prvej polovice pätdesiatych rokov redukoval autorskú slobodu na súhlasný schematizmus. Literárna teoretička Jelena Paštéková v tejto súvislosti uvádza: „Teória bezkonfliktovosti sa dotkla literárnych diel, aj podstaty dramatických umení a úplne dezorientovala spisovatel'ov, ktorí pri najlepšej vôli nedokázali vdýchnut život nekonfliktným, laboratórne vypreparovaným hrdinom. Podobne na tom bola aj satira so svojím pranierovaním negatívnych spoločenských javov.“31

Objektom satirického zobrazenia v tomto období mohlo byt' len to, čo kritizovala a odsudzovala samotná totalitná ideológia: napr. odporcovia kolektivizácie a budovania socializmu (kulaci, malomeštiaci, buržoázia), príslušníci inteligencie, veriaci či všeobecne spoločenské pomery spred februára 1948. Satira sa z politických dôvodov obmedzovala na kritiku a zosmiešňovanie nedostatkov každodenného l'udského prežívania. Chýbala jej spoločenskokritická híbka, takže bola často označovaná ako „ko-

\footnotetext{
${ }^{28}$ LASICA, M. - SATINSKÝ, J. Márna lásky snaha. In LES 2, s. 173.

${ }^{29}$ Tamže, s. 177.

${ }^{30}$ Tamže, s. $167-168$.

${ }^{31}$ PAŠTÉKOVÁ, J. K poetike pätdesiatych rokov. In Poetika a politika, s. 95.
} 


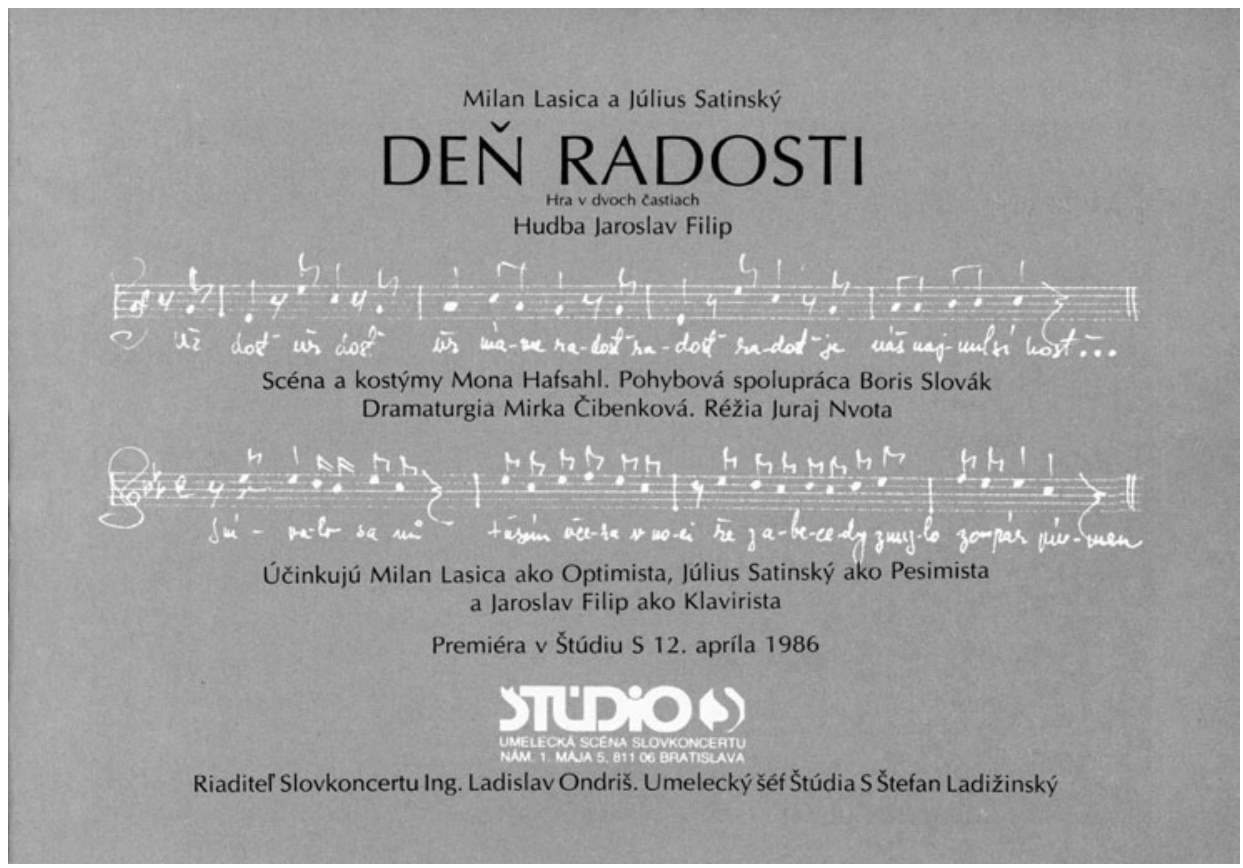

Milan Lasica - Július Satinský: Deň radosti. Štúdio S, premiéra 12. 4. 1986. Bulletin. Foto Archív Divadelného ústavu.

munálna“"32. Po smrti Josifa Vissarionoviča Stalina (1953) sa v Československu uskutočnila diskusia o novej funkcii satiry a jej úlohe v intenciách poetiky socialistického realizmu. ${ }^{33}$ Stigma protištátnosti satirického zobrazovania spoločenských problémov bola zmiernená, čo sa prejavilo napríklad v textoch Petra Karvaša, konkrétne v zbierkach poviedok Čert nespí (1954) a Čertovo kopýtko (1957). Paštéková v tejto súvislosti poznamenáva, že „Karvašove postavy chcú a začínajú žit’ súkromne, a vôbec to neznamená triedne nepriatel'stvo“34.

Hra Lasicu a Satinského Deň radosti pozostáva z dvoch častí. Vystupuje v nej menší počet postáv, čo je symptomatické pre autorské gesto i dramaturgiu diel L+S. Protagonisti Optimista a Pesimista sa javia ako úzko vyprofilované, kontrastné osobnosti. Kornel Földvári kreácie charakterizoval takto: „Lasicov part doviedol po hranicu dokonalosti anglickú lakonickost’ a flegmatický cynizmus mefistovského intelektuála - pod touto fasádou však nad’alej ostáva smutným klaunom dvojice. Kým Satinského Pesimista je neštastný - z rán, ktoré naňho dopadajú zvonku, Lasicov Optimista je smutný celým vnútorným uspôsobením. “35

${ }^{32}$ MARČOK, V. et al. Dejiny slovenskej literatúry III. Bratislava : Literárne informačné centrum, 2006, s. 174.

${ }^{33}$ Viac pozri PAŠTÉKOVÁ, J. K poetike pätdesiatych rokov. In Poetika a politika, s. 52.

${ }^{34}$ Tamže.

${ }^{35}$ FÖLDVÁRI, K. Milan Lasica a Július Satinský. In Dejiny slovenskej drámy 20. storočia, s. 563. 
V úvode drámy Pesimista predkladá svoj návrh na Deň radosti, ktorý by mal byt’ stretnutím l'udí za účelom zábavy. Z hl'adiska očakávaní, aké majú od tohto dňa jednotliví protagonisti, sú mená postáv a ich povahy, ktoré majú reprezentovat', navzájom inverzné. Pesimista je v skutočnosti optimistom a očakáva vel’a návštevníkov, Optimista neočakáva nikoho a je voči tomuto dňu skeptický. Tento jav môžeme priblížit na príklade nasledujúcej pasáže:

„PESIMISTA: Niet nad pevnú vieru. To je to, čo mi chýba. Celé moje videnie sveta je hlboko pesimistické. Ani teraz neverím. Neverím, že by nám niečo mohlo prekazit’ Deň radosti.

OPTIMISTA: Kde sa len vo vás berie tol'ko pesimizmu? Ja pevne verím, že to nevyjde. Spol'ahnite sa." 36

Na rozdiel od hlavných postáv, Klavirista ako d’alší protagonista hry pôsobí v danej situácii nezainteresovane. V dráme plní funkciu spájania jednotlivých výstupov. Vytvára intermezzá, po ktorých prerušený dej vzápätí opät pokračuje.

Oslabený sujet je postavený na humornom motíve, ktorý spočíva v tom, že počas samotnej realizácie hry sa traja herci vzájomne dohovárajú o tom, ako budú hrat', teda nehrajú v skutočnom zmysle slova. S uvedenou skutočnostou úzko súvisí aj prelínanie reálneho času s retrospektívou, čím sa na javisku akoby konštruovali dve paralelne plynúce dejové línie. Optimista predstavuje postavu, ktorá nevie tieto dve súbežné línie rozoznat'. Je teda de facto protagonistom, ktorý sa zúčastňuje sujetu, hoci v obsahovej rovine svojho prehovoru stojí mimo neho.

„OPTIMISTA: Asi ho odvolali.

PESIMISTA: Kam?

OPTIMISTA: Do ústavu.

PESIMISTA: Do výskumného?

OPTIMISTA: Ktovie. Ked’ nešiel tak dlho, možno do nápravného.

(...)

PESIMISTA: Zahrajte nadriadeného.

OPTIMISTA: Akurát! Chvílu si pohrám a potom šup do ústavu!

PESIMISTA: Nesmiete to brat' doslovne.

OPTIMISTA: Ale ved' to tak bolo, nie?

PESIMISTA: V skutočnosti. Ale v umeleckej retrospektíve...? Čo? Nemusí to byt' tak, ako to bolo naozaj... čo? Sám ste to povedali." ${ }^{\text {37 }}$

Prvá čast’ hry sa otvára uvažovaním postáv nad pojmom radost’, nad tým, čo ju spôsobuje. Pesimista vyslovuje túžbu po tom, aby sa radovali všetci l'udia spoločne, nadriadenému navrhuje zorganizovanie Dňa radosti. Úmyselnou kumuláciou slova radost’ sa vytvára efekt neprirodzeného úsilia o násilné dotlačenie l'udí k pocitu štastia:

„PESIMISTA: Radost'. Radost', radost', radost'. Radost’ pre všetkých. Všetci všetkým, každý každému, ty mne, ja tebe, on jej, ona jemu, my vám, vy nám, oni im, ony nám... (...) radosṫ... potešíme vás... ja ju, ona mňa, ty jeho, on vás, my nás, ja teba, aj ty mňa... skrátka, všetci všetkých. Radost', radost', radost'. Príd'te, príd'te, príd'te. Kto nepríde, ol'utuje..." ${ }^{\text {38 }}$

${ }^{36}$ LASICA, M. - SATINSKÝ, J. Deň radosti. In LES, s. 283 - 284.

37 Tamže, s. 277.

38 Tamže, s. 292. 
Satirické odkazovanie na ideologický diktát v oblasti umenia je z hladiska umeleckých prostriedkov vyjadrený hyperbolou, ked’že prirodzenost' l'udského prežívania nemôže byt' vynucovaná politickou mocou. V pätdesiatych rokoch boli spisovatelia indoktrinovaní, aby v tvorbe umelecky zobrazovali budovatel'ský optimizmus. Pochyby o politickom smerovaní spoločnosti by mohli destabilizovat monolit komunistickej moci, preto stvárňovanie pocitov smútku a dezilúzie stálo v antagonistickej pozícii k povinnej optimistickej vízii budúcnosti. Propagandistické potláčanie smútku a vnucovanie radosti teda u Lasicu a Satinského nadobúda satirický rozmer. Vytváraním motívu „radosti na povel“ dráma paradoxne získava vnútorný protipól, a to neradostný pocit a pochmúrnu atmosféru. Uvedený motív radosti, ale aj charakterizácia protagonistov a výber názvu diela smeruje $\mathrm{k}$ paródii na poetiku hesiel jazyka socialistického realizmu.

V tejto súvislosti v krátkosti spomeňme dobovú polemiku o „práve básnika na smútok", ktorá mala výrazný dopad na d’alšie smerovanie tvorby slovenských spisovatel’ov. Polemické vystúpenie inicioval v roku 1957 básnik Ivan Mojík svojou kritickou reakciou na básnický debut Milana Rúfusa $A z ̌$ dozrieme (1956). V článku s názvom Objektíonost', nie okiadzanie (Niekol'ko poznámok k veršom Milana Rúfusa) zdôrazňuje potrebu umeleckého reflektovania obrazu človeka dneška, pričom sa odvoláva na už uskutočnený zjazd spisovatelov a jeho programové heslá, v ktorých nebol priestor pre vyjadrovanie skepsy, smútku či strachu z budúcnosti. Aj Mojík uprednostňuje jednostranný optimizmus v básnickej tvorbe, ktorý Rúfus charakterom svojej zbierky narúša. ${ }^{39}$ Podla literárneho teoretika Pavla Matejoviča, odmietanie smútku v tomto období nadobudlo ritualizačný charakter, smútok bol subjektivizovaný ako forma psychickej „úchylky“ alebo bol označený za prejav „buržoáznej dekadencie“. ${ }^{40}$ Práve vnútený budovatel'ský optimizmus poskytol Lasicovi a Satinskému úrodnú pôdu pre ich satiru. Vedomí si toho, že individuálne l’udské prežívanie nemožno násilne ovplyvňovat', tak nepriamo nadväzujú na citovanú polemiku Mojíka a Rúfusa.

Druhá čast’ divadelnej hry prechádza k bilancovaniu nevydareného Dňa radosti. Pesimista víta prvého návštevníka, no zároveň sa dozvedá, že je jediným prichodiacim: „(...) vítame vás... willkommen... dobro došli... tu sme... vítame vás, vel'kí, malí, v tomto našom areáli... smiech, smiech, smiech - nie je hriech... kto nie je sysel', pre radost' má zmysel, my nie sme sysle, veselej sme mysle... hop, hop, hop - žial'u kopem hrob... (Až po chvíli zbadá, ako sa na neho Optimista začudovane díva, vypne magnetofón.) To ste vy? A kde sú l’udia?"41

V závere druhej časti sa inverzná charakteristika postáv Optimistu a Pesimistu mení a označenie protagonistov sa začína zhodovat’ s ich vlastnostami:

„PESIMISTA: Radosṫ... to slovo ani nevyslovujte... (Strká hlavu do slučky.) Ani správu o tej neštastnej akcii som nemohol odoslat'.

OPTIMISTA: Prečo?

PESIMISTA: A čo som tam mal napísat? Fiasko? Bodka?

${ }^{39}$ MOJÍK, I. Objektívnost', nie okiadzanie (Niekol'ko poznámok k veršom Milana Rúfusa). In Mladá tvor$b a, 1957$, roč. 2 , č. $6-7$, s. 174 .

${ }^{40}$ MATEJOVIČ, P. Slzy si utřeme pěstí (Diskusie o práve básnika na smútok v slovenskom literárnom prostredí v druhej polovici 20. storočia a ich český kontext). In Česká literatura, 2020, roč. 68, č. 2, s. 182 - 203.

${ }^{41}$ LASICA, M. - SATINSKÝ, J. Deň radosti. In LES, s. 303. 
OPTIMISTA: Prečo tak kategoricky? Napriek chudobnej účasti... odhliadnuc od komplikácií... maximálne vypätie... minimálne straty. “ ${ }^{2}$

Optimista s Klaviristom vzápätí upozornia na divákov sediacich v javisku divadla, ktorí predsa len na Deň radosti prišli. Touto scénou sa zotierajú hranice medzi fikčným svetom divadelnej hry a jej dramatickou realizáciou na javisku. Prichádza k búraniu tzv. štvrtej steny, k narušeniu ilúzie, ktorá oddeluje javisko od hladiska. Následná snaha Pesimistu o ukončenie svojho života obesením generuje drsnú pointu: až počas toho, ako má slučku na krku, začínajú prichádzat’ očakávaní hostia, ktorých dokázala upútat’ len táto "senzácia“.

Ako konštatuje Földvári, Deň radosti „netvorí dynamicky vypätý príbeh a prudko sa ženúci dej - pri rozvinutí konfliktu vystačia autori s jemne gradovanou hrou s časovými rovinami či s rekonštrukciou udalostí a ich analýzou“43. V porovnaní s predošlými textami sa vyznačuje priamočiarostou, s akou autori smerujú k podstate. Tragickost je zobrazená exaktne (tragikomédia prechádza k tragédii), čo potvrdzuje aj pieseň Pokus o útek, zobrazujúca neschopnost' medziludskej komunikácie v súčasnej spoločnosti, bezvýchodiskovú situáciu človeka a jeho následnú kapituláciu.

Divadelná hra Deň radosti sa stretla u literárnej kritiky s vel'kou odozvou. V súvislosti s obdobím jej vzniku ju básnik a literárny vedec Ján Brezina dokonca označuje za vrcholné dielo L+S: „Reprodukovat’ dialógy Optimistu a Pesimistu, spôsob, akým využívajú zaužívané slovné spojenia, reprodukovat' logiku ich argumentov, názory na poslanie umenia, hl'adat' skryté či otvorené paródie života okolo nás presahuje rámec tohto textu. Hru pokladám za vyvrcholenie ich doterajšej tvorby. Lasica a Satinský v nej dospeli takmer k všeobecnej platnosti, k všeobecnému dosahu (...). ${ }^{44}$

\section{Náš priatel' René}

Dramatická realizácia diela Náš priatel' René s podtitulom Volne podl’a J. I. Bajzu nadväzuje na pretext - román Jozefa Ignáca Bajzu René mlád’enca príhodi a skúsenosti (1783). ${ }^{45}$ Satirická adaptácia Lasicu a Satinského mala mat’ premiéru v januári 1980, no po zásahu ministerstva kultúry sa neuskutočnila. Prvá inscenácia bola uvedená až o jedenást’ rokov (1991) vo vtedajšom Štúdiu S.

Už samotný názov textu poukazuje na postoj protagonistov, ktorí Reného vnímajú ako svojho priatel’a. Ak by sme však na slovo náš nazerali v zmysle kolektívu, potom v spojení s pojmom priatel' a významom mena René (z lat. znovuzrodený) evokuje človeka s náklonnostou či pozitívnym vzt̉ahom k novátorstvu. Preto je výber mena René zámerný z hl'adiska jeho priradenia k osobe so zmyslom pre neustále vzdelávanie sa a cestovanie, čo vedie k akémusi „oživeniu“. Tu vzniká konflikt medzi názvom drámy a zobrazovaným fikčným svetom, kde dvaja dramatici parodujú a karikujú slovenskú náturu ako nevyvíjajúcu sa, bez túžby po d’alšom vzdelávaní či objavovaní nového.

\footnotetext{
${ }^{42}$ Tamže, s. 323.

${ }^{43}$ FÖLDVÁRI, K. Milan Lasica a Július Satinský. In Dejiny slovenskej drámy 20. storočia, s. 562.

${ }^{44}$ BREZINA, J. Komičnom k identifikácii a naspät'. In Dotyky, 1989, roč. 1, č. 7, s. 40.

${ }^{45}$ O adaptáciu Bajzovho románu sa pokúsil aj L'ubomír Feldek (Van Stiphout, 1980).
} 
„VAN STIPHOUT: Toto je ručička. Ako na hodinkách.

ĎURO: A čo ma po nej.

VAN STIPHOUT: A tá vám furt ukazuje, kde je sever.

ĎURO: Aj podl'a machu viem.

VAN STIPHOUT: Ked’ nebude machu, ručička vám ukáže.

ĎURO: Machu je dost'.

VAN STIPHOUT: Ale mach je na strome len z tej strany, kde je sever, a s týmto sa môžete krútit', ako chcete, a ručička stále na sever ukazuje.

ĎURO: A čo by som sa krútiu?

VAN STIPHOUT: $S$ týmto by ste v hore nezablúdili.

ĎURO: Horu ja poznám. A machu je dost'.

VAN STIPHOUT: A keby ste boli na mori?

ĎURO: A čože by som ja na mori robiu? V hore mi je dobre." ${ }^{46}$

Z formálneho hl'adiska sa pôvodný román aj divadelná hra delia na dve časti. Kým prvý diel má cestopisný charakter s dobrodružnými a didaktickými prvkami (Bajza recipientovi demonštruje život vo vzdialených krajinách, ich náboženstvo, mravy a zvyky), druhý diel je realizovaný reportážnym a anekdotickým spôsobom. Bajza zužitkoval epigramy zo svojej zbierky Rozličné verše, ostro kritizujúcej cirkev na Slovensku i neresti prostého slovenského l’udu, ktorá ostala nedokončená kvôli zásahom cirkevnej cenzúry. V divadelnej hre Náš priatel' René vystupuje niekol'ko postáv z pôvodného románu (Van Stiphout, Don Varlet) a zopár nových postáv (Pal’o, Ďuro, notár, adjunkt). Paradoxne, René ako klúčový protagonista absentuje. Postavy Ďura a Pal'a, ktoré pretext neobsahuje, reprezentujú prototyp nižšej vzdelanostnej vrstvy, prostých Slovákov. Na základe používaného dialektu v prehovoroch postavy Ďura zarad’ujeme jeho repliky do záhoráckeho nárečia a Pal’ove do liptovského. Vzniká tak kontrast založený na dialektologickej báze, ktorý spočíva v rozdielnostiach západoa stredoslovenského nárečového makroareálu. Prostredníctvom vyššie zmienených protagonistov Lasica so Satinským tematizujú riešenie tzv. jazykovej otázky, ktorú možno považovat’ za významnú alúziu na románovú predlohu. Bajza sa v nej totiž zaoberá zjednotením spisovnej reči oboch vel'kých cirkevných obcí Slovákov a Lasica so Satinským na túto problematiku metatextovo nadväzujú.

Dielo René mlád’enca príhodi a skúsenosti figuruje v rámci slovenského literárneho kánonu ako prvý román, no satirická hra Náš priatel René je od žánru románu zretel'ne diferencovaná, uvádza sa s ironickým podtitulom Monumentálna historická freska s prestávkou. Do vel'kej miery je založená nielen na odlišnosti z hl'adiska uplatneného žánru, ale aj na zvýraznení protikladného prostredia a postáv. Na jednej strane autori uvádzajú čitatelov a divákov do vznešených Benátok, na strane druhej je dej lokalizovaný do slovenskej krčmy. Dramatici ju vyberajú zámerne ako stereotypizované prostredie slovenskej dediny, je miestom združovania sa komunity miestnych obyvatel’ov a do istej miery aj satiricky chápanou „kultúrou“ Slovákov.

V iniciačnom príhovore je identifikovatel’ný ironizujúci pohl’ad na staršie romány, ktoré protagonisti považujú za málo čitatel'sky prítažlivé. Ako príklad slúži práve predloha ich hry. Jej výber divákom zdôvodňujú:

${ }^{46}$ LASICA, M. - SATINSKÝ, J. Náš priatel' René. In LES 2, s. 190 - 191. 


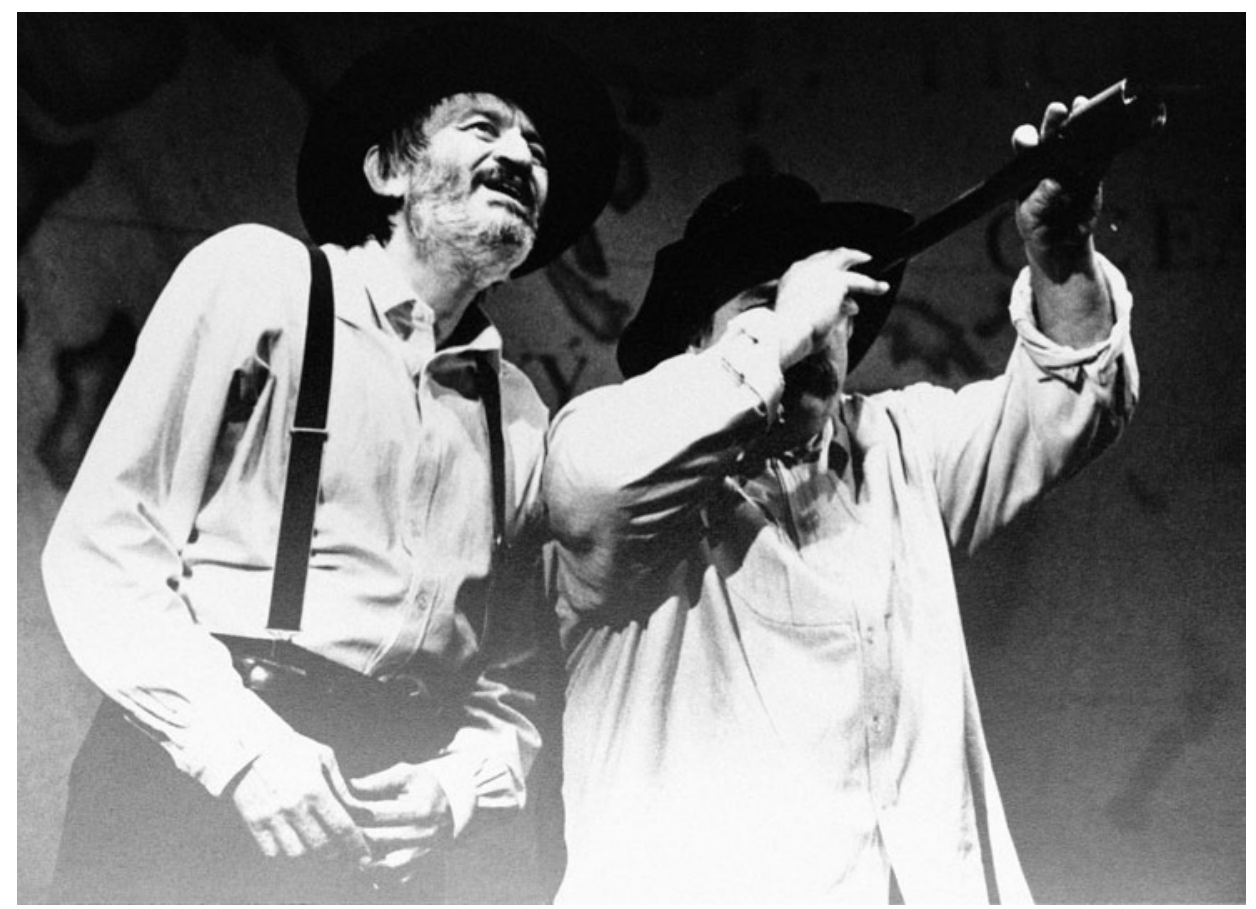

Milan Lasica - Július Satinský: Náš priatel' René. Štúdio S, premiéra 8. 11. 1991. Réžia Jaroslav Filip. Účinkujúci Milan Lasica, Július Satinský. Foto Archív Divadelného ústavu. Snímka Jozef Uhliarik.

„2. HEREC: Iste sa čudujete, prečo sme sa práve my dvaja rozhodli venovat celý večer Bajzovi. Je to preto, že my dvaja sme jediní, ktorí Bajzu čítali.

1. HEREC: Bolo tu v minulosti zopár pokusov dočítat René mládenca príhody a skúsenosti až do konca. Ale úporný zápas s bajzovskou slovenčinou, ako aj úporný zápas s driemotami premohol mnohých zarytých nadšencov. ${ }^{\text {} 47}$

Citovaná pasáž parodizujúcim spôsobom naznačuje iluzórny didaktický aspekt textu v konštatovaní, že postavy hry sú jediné, ktoré Bajzov román prečítali. Divákov zároveň oboznamujú s obdobím a prostredím deja. Týmto úvodom parodujú predhovor Bajzovho románu (autor sa v ňom vopred ospravedlňuje za možné chyby a nedostatky, zároveň obhajuje svoj jazyk a v ňom používané západoslovenské nárečie i prvky z lexiky českého jazyka). Do zložitého románového sujetu vkladajú Lasica so Satinským alúzie na iné literárne postavy diel literárneho kánonu, či už európskej alebo americkej literatúry.

„2. HEREC: V románe sa to len tak hmýri postavami. Až človek chvílami stráca orientáciu. Je Bolkonskij brat a či švagor, Bezuchov sa tvári ako keby nič, Clyde ju sotí do vody, Raskol'nikov vytiahne sekeru, človek znervóznie, rozbolí ho hlava. ${ }^{48}$

\footnotetext{
${ }^{47}$ Tamže, s. 180 .

${ }^{48}$ Tamže, s. 179.
} 
Výber spomenutých prvkov intertextuálneho nadväzovania je zámerný, so snahou ironizovat' zdĺhavost' deja a neprehl'adnost' vztahu medzi postavami v románoch. Popri alúziách tu nájdeme metatextové odkazy, napríklad na poéziu generácie slovenských romantikov. Sujet sa do značnej miery inšpiroval Bajzovým románom, no je rozšírený o satirické prvky založené na inter- a intratextuálnom odkazovaní. Prostredníctvom stretnutia s talianskym gondolierom, anglickým kapitánom lode a africkým domorodcom autori parodujú vlastnosti ako závist', sklony k alkoholizmu a večnému stažovaniu sa:

„DON VARLET: Prečo tak bedákaš, milý domorodec, stratil si niečo? Pýtam sa, prečo tak bedákaš? Vari si stratil reč?

(...)

VAN STIPHOUT: Salem alejkum, sahib. Nebedákam. Modlím sa k Alahovi, lebo on je mocný.

DON VARLET: Ty sa modlíš, ale ja bedákam, aj ked’ bedákanie nie je našou národnou vlastnostou. ${ }^{\prime 49}$

V týchto stretnutiach Lasica so Satinským zároveň vytvárajú satirický pastiš, ktorý kombináciou nedomácich jazykových prvkov so slovenčinou tvorí navonok nesúrodý dojem, pričom toto spojenie vytvára komický akcent. Do scény návratu Dona Varleta a Van Stiphouta je zakomponované aj ich zoznámenie sa s notárom a adjunktom. V príslušnom dialógu uvádzajú už aj svoje pôvodné mená, namiesto pseudonymov sa priznávajú k slovenskému pôvodu. Predstieraná vzdelanost' postáv Dona Varleta a Van Stiphouta sa vd’aka tomuto odhaleniu dostáva do iného svetla. Punc vznešenosti ich pseudonymov zaniká, exotický lesk je nahradený regionálnou všednost’ou slovenských mien Števo Kracina a Jozef Pučiak.

Napriek humornej a satirickej línii identifikujeme $\mathrm{v}$ texte deziluzívne prvky a smútok nad stavom spoločnosti. Pocit sklamania sa naprieč celou hrou demonštruje niekol'ko ráz vysloveným prehovorom: "Juj, bôl'no mi na duši.“50 Zintenzívnenie tohto pocitu nastáva v závere drámy, kde sa daná konštrukcia posledný raz opakuje a bezprostredne po nej nasleduje Palov prehovor: „Šak aj mne. O tem potem. “51

\section{Záver}

Nebolo by korektné zúžit výrazové aspekty komiky textov Milana Lasicu a Júliusa Satinského iba na satiru. Pracujú so širokou paletou výrazových prostriedkov, od irónie cez sarkazmus, hyperbolu, paródiu až po jazykovú komiku. Satirický akcent však formálne dominuje a menované prostriedky zastrešuje do svojskej žánrovej podoby, ktorá je skôr humanistická než výsmešná či útočná. Humor s l’udskou tvárou, ako by sme ho mohli metaforicky nazvat', Lasica so Satinským hladajú v psychike, myslení a vlastnostiach človeka. ${ }^{52}$ Dvojica sa prezentovala komikou primárne karikujúcou l'udské vlastnosti, takže sa nedá ju redukovat’ len na politickú satiru. Nemožno ich teoreticky zaradit do žiadnej z už existujúcich umeleckých skupín či programov, ich tvorba sa vymyká bližšiemu žánrovému zaradeniu. Humor slovenského divadelníc-

\footnotetext{
${ }^{49}$ Tamže, s. 193.

50 Tamže, s. 182.

51 Tamže, s. 223.

52 FÖLDVÁRI, K. Svet pre dvoch, s. 10.
} 
tva druhej polovice 20. storočia obohatili o novú dimenziu, ktorú Martin Porubjak nazýva konkretizovanou absurditou ${ }^{53}$. Miloš Mistrík v zhode s Porubjakom konštatuje, že sa dostali „spomedzi slovenských dramatikov najbližšie k híbkovému poznaniu, osobnému pochopeniu či dokonca stotožneniu sa s duchom a obsahom absurdnej dramatiky“54.

Je však dôležité podotknút', že humoristický štýl autorov a charakter ich satirického zobrazovania postupne prechádzal vývinovými metamorfózami. Od živosti a optimizmu v raných hrách dospeli k postupnému akcentovaniu presne zacielenej ofenzívnosti, čo je zretel’ne čitatelné už v dramatických textoch Soirée a Radostná správa. Ich útočnost' je nasmerovaná proti totalitnej mašinérii a jej ideologickej propagande. Kornel Földvári hl'adá túto ofenzívnost’ v hlbších významových vrstvách textu, až $\mathrm{v}$ polohe demaskovania absurdnosti ${ }^{55}$, nie však do politickej pozície. Literárny vedec Oleg Sus hovorí o akejsi emocionálnej krivke ${ }^{56}$, z ktorej sa vyvinul aj humor Lasicu a Satinského: ich satira nadobúda svojskú formu, v tej je možné interpretovat' na jednej strane smiech a veselost', na druhej strane hnev a kritickost'. Kritickost' nie je nasmerovaná náhodne, je explicitne zacielená do záležitostí aktuálnych, „satira musí žit" ${ }^{257}$.

Novátorstvo, ktorým sa Lasica a Satinský zapísali do dejín slovenského divadla, prejavujúce sa napríklad v dôraze na slovo ako výstavbový prvok celej drámy, nemalo predchodcov ani pendantov, na ktorých by mohla autorská dvojica nadviazat'. Ich tvorba svojím charakterom vybočovala z cesty opisno-realistickej tradície. Azda by sme teda mohli uvažovat o akejsi „estetickej revolúcii“, o rozbití dovtedajšieho dramatického kánonu. Földvári dokonca hovorí o zastaranom humore ${ }^{58}$, aký dovtedy v našom divadelníctve prevládal a do ktorého sa Lasica a Satinský ani nepokúšali vtesnat'.

\section{SPECIFIC FORMS OF SATIRE IN THE DRAMATIC REALISATIONS OF MILAN LASICA AND JÚLIUS SATINSKÝ}

\section{Lenka HALUZOVÁ}

The study employs literary-theoretical knowledge from the field of comedy, emphasising satire as an expressive element of comicality. The study focuses on a comparison between literary source texts and their adaptations in the drama creation of Milan Lasica and Július Satinský. The study identifies satirical elements present in these adaptations as a result of genre shifts between pretext and posttext within the corresponding period context of the origin of the works.

Text vznikol v rámci doktorandského štúdia na Pedagogickej fakulte Trnavskej univerzity v Trnave, školitel' Juraj Hladký.

\footnotetext{
${ }^{53}$ PORUBJAK, M. Lasica \& Satinský \& my. In LES, s. 340.

${ }^{54}$ MISTRÍK, M. Slovenská absurdná dráma, s. 112.

${ }^{55}$ FÖLDVÁRI, K. Svet pre dvoch, s. 165.

${ }^{56}$ SUS, O. Metamorfózy smíchu a vzteku. Brno : Krajské nakladatelství, 1963, s. 53.

${ }^{57}$ Tamže, s. $53-54$.

${ }^{58}$ FÖLDVÁRI, K. Milan Lasica a Július Satinský. In Dejiny slovenskej drámy 20. storočia, s. 560.
} 


\section{LITERATÚRA}

BACHTIN, Michail Michailovič. Francois Rabelais a lidová kultura středověku a renesance. Praha : Argo, 2007. 490 s. ISBN 978-80-7203-776-6.

BORECKÝ, Vladimír. Imaginace, hra a komika. Praha : Triton, 2005. 352 s. ISBN 80-7254-503-5.

BREZINA, Ján. Komičnom k identifikácii a naspät. In Dotyky, 1989, roč. 1, č. 7, s. 40.

BŽOCHOVÁ-WILD, Jana. Shakespeare. Zooming. Bratislava : Európa, 2017. 238 s. ISBN 978-8089666-49-2.

DOLEŽEL, Lubomír. Heterocosmica. Praha : Karolinum, 2003. 311 s. ISBN 80-246-0735-2.

FÖLDVÁRI, Kornel. Milan Lasica a Július Satinský. In Dejiny slovenskej drámy 20. storočia. (Ed. Vladimír Štefko). Bratislava : Divadelný ústav Bratislava, 2011, s. 559 - 564. ISBN 97880-89369-36-2.

FÖLDVÁRI, Kornel. Svet pre dvoch. Levice : Koloman Kertész Bagala, 2004. 125 s. ISBN 8089129-14-5.

JABORNÍK, Ján. Vývinové premeny slovenskej divadelnej réžie a generačná otázka. In Poetika a politika. Bratislava : Ústav slovenskej literatúry SAV, 2004, s. 129 - 154. ISBN 80-88746-14-0.

JEDLIČKOVÁ, Alice - FEDROVÁ, Stanislava. Obraz v př́iběhu - ekfráze ve vyprávění. Předběžné návrhy k rozlišení popisnosti a vizuality. In Slovenská literatúra, 2010, roč. 57, č. 1, s. 29 - 59. ISSN 0037 - 6973.

KASARDA, Martin. Povedz mi, čo čítaš, čiže dlhšia prechádzka súčasnou literatúrou čast’ 3. In Dotyky, 1997, roč. 9, č. 3, s. $52-54$.

LACZKOVÂ, Margita. Niektoré súvislosti medzi groteskou a postmodernizmom. In Romboid, roč. 29,1994, č. 6, s. $50-60$.

LASICA, Milan - SATINSKÝ, Július. Deň radosti. In LES. Levice : Koloman Kertész Bagala, 1996, s. 266 - 325. ISBN 80-967516-6-2.

LASICA, Milan - SATINSKÝ, Július. Márna lásky snaha. In LES 2. Levice : Koloman Kertész Bagala, 1998, s. 167 - 177. ISBN 80-88897-27-0.

LASICA, Milan - SATINSKÝ, Július. Náš priatel' René. In LES 2. Levice : Koloman Kertész Bagala, 1998, s. 178 - 223. ISBN 80-88897-27-0.

MARČOK, Viliam. Dejiny slovenskej literatúry III. Bratislava : Literárne informačné centrum, 2006. 496 s. ISBN 80-89222-08-0.

MATEJOVIČ, Pavel. Slzy si utřeme pěstí (Diskusie o práve básnika na smútok v slovenskom literárnom prostredí v druhej polovici 20. storočia a ich český kontext). In Česká literatura, 2020 , roč. 68 , č. 2, s. $182-203$. ISSN 0009-0468.

MISTRÍK, Miloš. Slovenská absurdná dráma. Bratislava : VEDA, 2002. 254 s. ISBN 80-224-0713-5.

MOJÍK, Ivan. Objektívnost', nie okiadzanie (Niekol'ko poznámok k veršom Milana Rúfusa). In Mladá tvorba, roč. 2, 1957, č. 6-7, s. 174.

PAŠTÉKOVÁ, Jelena. K poetike pätdesiatych rokov. In Poetika a politika. (Ed. Jelena Paštéková). Bratislava : Ústav slovenskej literatúry SAV, 2004, s. 32 - 57. ISBN 80-88746-14-0.

PAVIS, Patrice. Divadelný slovník. Bratislava : Divadelný ústav, 2004. 542 s. ISBN 80-88987-24-5.

PORUBJAK, Martin. Lasica \& Satinský \& my. In LES. Levice : Koloman Kertész Bagala, 1996, s. 327 - 341. ISBN 80-967516-6-2.

SUS, Oleg. Metamorfózy smíchu a vzteku. Brno : Krajské nakladatelství, 1963. 161 s.

ŠTEFKO, Vladimír. Dráma slúžkou ideológie 1948 - 1960. In Dejiny slovenskej drámy 20. storočia. (Ed. Vladimír Štefko). Bratislava : Divadelný ústav Bratislava, 2011, s. 319 - 350. ISBN 97880-89369-36-2.

ŠTEFKO, Vladimír. Roky šest'desiate a d’alšie. In Dejiny slovenskej drámy 20. storočia. (Ed. Vladimír Štefko). Bratislava : Divadelný ústav Bratislava, 2011, s. 453 - 498. ISBN 978-80-8936936-2.

ZAJAC, Peter. Štylistika, rétorika, poetika. In Od moderny k postmoderne. (Ed. Tibor Žilka). Nitra : Univerzita Konštantína Filozofa v Nitre, 1997, s. 29-42. ISBN 80-8050-122-X. 
ŽILKA, Tibor. (Post)moderná literatúra a film. Nitra : Univerzita Konštantína Filozofa v Nitre, 2006. 188 s. ISBN 80-8094-041-X.

ŽILKA, Tibor. Text a posttext. Nitra : Univerzita Konštantína Filozofa v Nitre, 2011. 161 s. ISBN 978-80-8094-874-8.

Lenka Haluzová

Pedagogická fakulta

Trnavská univerzita

Priemyselná 4

91843 Trnava

e-mail: lenka.haluzova@gmail.com 